\title{
Approximating Tasseled Cap Values to Evaluate Brightness, Greenness, and Wetness for the Advanced Land Imager (ALI)
}

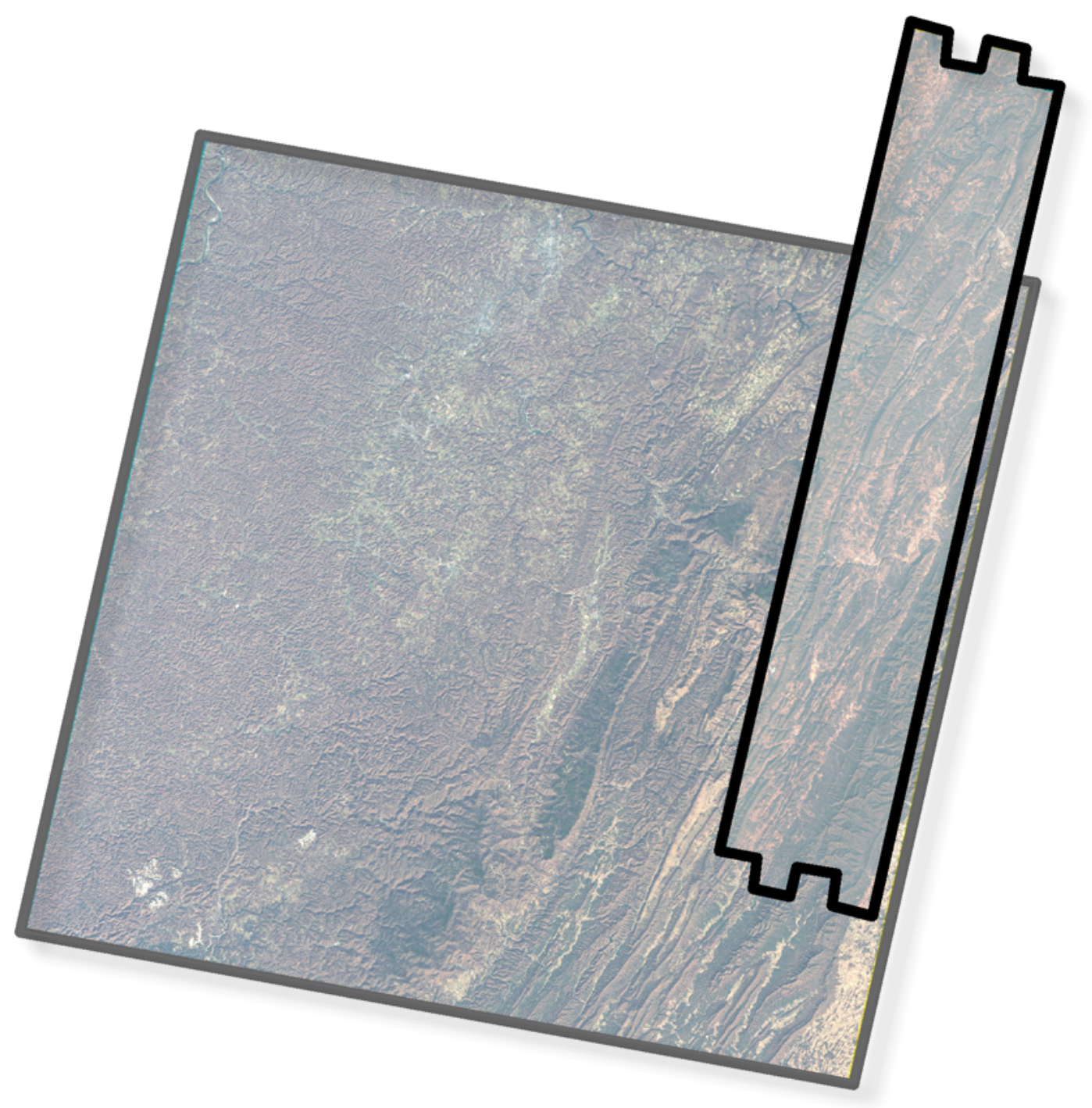

Scientific Investigations Report 2012-5057 



\section{Approximating Tasseled Cap Values to Evaluate Brightness, Greenness, and Wetness for the Advanced Land Imager (ALI)}

By Kristina H. Yamamoto and Michael P. Finn

Scientific Investigations Report 2012-5057 


\title{
U.S. Department of the Interior \\ KEN SALAZAR, Secretary \\ U.S. Geological Survey \\ Marcia K. McNutt, Director
}

\author{
U.S. Geological Survey, Reston, Virginia: 2012
}

For more information on the USGS - the Federal source for science about the Earth, its natural and living resources, natural hazards, and the environment, visit http://www.usgs.gov or call 1-888-ASK-USGS.

For an overview of USGS information products, including maps, imagery, and publications, visit http://www.usgs.gov/pubprod

Any use of trade, product, or firm names is for descriptive purposes only and does not imply endorsement by the U.S. Government.

Although this report is in the public domain, permission must be secured from the individual copyright owners to reproduce any copyrighted materials contained within this report.

Suggested citation:

Yamamoto, K.H., and Finn, M.P., 2012, Approximating tasseled cap values to evaluate brightness, greenness, and wetness for the Advanced Land Imager (ALI): U.S. Geological Survey Scientific Investigations Report 2012-5057, 9 p. 


\section{Contents}

Abstract
Introduction
Methods
Study Sites and Dataset
Description of Methods
Discussion
References Cited

\section{Figures}

1. Map showing location of study sites.................................................................................

2. Flowchart illustrating steps to convert the original imagery to radiance,

3. Map showing ALI image superimposed over Landsat 5 image (row 17 path 33)

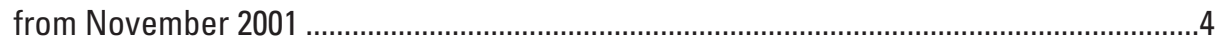

4. Graph showing ALI and Landsat TM TOA reflectance values for a sample point in the West Virginia, row 17 path 33, November 2001, image pair......................................6

5. Graphs showing ALI and Landsat TM TOA reflectance and TC values for Landsat band 2/ALI band 3 for the West Virginia, row 17 path 32, July 2007 image pair

6. Graphs showing ALI and Landsat TM TOA reflectance and TC values for Landsat band 3/ALI band 4 for the California, row 43 path 34, March 2003 image pair

\section{Tables}

1. Comparison of characteristics between Landsat TM, ETM+, and ALI...............................

2. Climate information for study sites ............................................................................

3. List of Landsat TM and ALI images used in the study ..................................................

4. $\mathrm{R}^{2}$ values for radiance, reflectance, and TC for each pair of images ...............................5

5. $\mathrm{R}^{2}$ values for radiance, TOA reflectance, and TC for Landsat ETM+ and ALI image pair ............................................................................................................

6. $\mathrm{R}^{2}$ values for radiance, TOA reflectance, and TC for Landsat ETM+ and ALI image after sampling algorithm run. 


\section{Conversion Factors}

Inch/Pound to SI

\begin{tabular}{|c|c|c|}
\hline Multiply & By & To obtain \\
\hline \multicolumn{3}{|c|}{ Length } \\
\hline inch (in) & 2.54 & centimeter $(\mathrm{cm})$ \\
\hline inch (in) & 25.4 & millimeter $(\mathrm{mm})$ \\
\hline
\end{tabular}

Temperature in degrees Fahrenheit $\left({ }^{\circ} \mathrm{F}\right)$ may be converted to degrees Celsius $\left({ }^{\circ} \mathrm{C}\right)$ as follows: ${ }^{\circ} \mathrm{C}=\left({ }^{\circ} \mathrm{F}-32\right) / 1.8$

SI to Inch/Pound

\begin{tabular}{|c|c|c|}
\hline Multiply & By & To obtain \\
\hline \multicolumn{3}{|c|}{ Length } \\
\hline meter (m) & 1.094 & yard (yd) \\
\hline
\end{tabular}




\title{
Approximating Tasseled Cap Values to Evaluate Brightness, Greenness, and Wetness for the Advanced Land Imager (ALI)
}

\author{
By Kristina H. Yamamoto and Michael P. Finn
}

\section{Abstract}

The Tasseled Cap transformation is a method of image band conversion to enhance spectral information. It primarily is used to detect vegetation using the derived brightness, greenness, and wetness bands. An approximation of Tasseled Cap values for the Advanced Land Imager was investigated and compared to the Landsat Thematic Mapper Tasseled Cap values. Despite sharing similar spectral, temporal, and spatial resolution, the two systems are not interchangeable with regard to Tasseled Cap matrices.

\section{Introduction}

Using remotely sensed data, researchers have patterned various flora biophysical variables that led to the creation and use indices for vegetation studies (Running and others, 1994; Jensen, 2005). Kauth-Thomas or Tasseled Cap (TC) transformations on remotely sensed image bands highlight the brightness, greenness, and wetness present in the images (Kauth and Thomas, 1976; Crist and Kauth, 1986). The TC transformation can be used in a variety of vegetation and soil studies, such as evaluating bark beetle effects on spruce forests (DeRose and others, 2011); mapping wildfire and deforestation activities (Schroeder and others, 2011); assessing soil salinity (Gutierrez and Johnson, 2010); and identifying shorelines (Ouma and Tateishi, 2006).

The TC transformation was designed primarily for Landsat Multispectral Scanner (MSS), Thematic Mapper (TM), and Enhanced TM (ETM+) data. For each sensor, a matrix of coefficients for the image bands was created. The Landsat MSS matrix was described by Crist and Cicone (1984); the Landsat TM by Crist (1985); and the ETM+ by Huang and others (2002). TC transformations also have been done for Moderate Resolution Imaging Spectroradiometer (MODIS) (Zhang and others, 2002; Lobser and Cohen, 2007), IKONOS (Horne, 2003), and Advanced Spaceborne Thermal Emission and Reflection Radiometer (ASTER) (Wang and Sun, 2005).
The U.S. National Aeronautic and Space Administration's (NASA) Earth Observing-1 (EO-1) satellite orbits in formation with Landsat 7. EO-1's Advanced Land Imager (ALI) sensor is the precursor to the operational land imager (OLI) instrument to be flown on the Landsat Data Continuity Mission (LDCM) and has similar spectral characteristics to Landsat TM and ETM+ (table 1). The spatial resolution (30 meters, nominally) remains standard for all three sensors and all bands, with the exception of thermal and panchromatic bands. The EO-1 orbit allows for ALI image acquisition within 1 minute of Landsat ETM + . The satellite also can perform cross-track pointing capability to focus on targets. ALI images have been used for multiple remote-sensing analyses [for example, mapping vegetation (Helmer and others, 2010); measuring seawater turbidity (Chen and others, 2009); characterizing soils (Bannari and others, 2008); and detecting ice sheet change (Bindschadler and others, 2010)]. Currently (2011), there is no widely accepted TC matrix for ALI images.

Verification of the radiometric calibration of the ETM+ and ALI image pairs previously has been done because of the similarities between the ETM+ and ALI images. The agreement within the visible and near-infrared bands is within 2 percent, whereas the agreement within the shortwave bands is slightly lower at 4 percent (Chander and others, 2004) in non or low vegetated areas. Agreement between bands in vegetated areas, or in areas with high aerosol loading, was not included in the study.

An investigation was done to determine if the coefficient matrices using reflectance values derived for Landsat TM (Crist, 1985) and ETM+ (Huang and others, 2002) could be applied to ALI images because of the widespread use of the TC transformation for vegetation and soil studies. If such a relation between Landsat TM and ALI existed, then the Landsat TM TC matrix could be used instead of developing a new TC matrix for ALI; therefore, the goal of this study is to determine the feasibility of product interchangeability between sensors. 
Table 1. Comparison of characteristics between Landsat TM, ETM+, and ALI.

[TM, Thematic Mapper; ETM+, Enhanced Thematic Mapper Plus; $\mu \mathrm{m}$, micrometer (one micrometer is equivalent to $1 \times 10^{-6}$ of a meter); ALI, Advanced Land Imager; --, no data; VNIR, visible and near-infrared; SWIR, short-wavelength infrared; TIR, thermal infrared]

\begin{tabular}{|c|c|c|c|c|c|}
\hline $\begin{array}{c}\text { Landsat } 5 \\
\text { TM/7 ETM+ } \\
\text { band number }\end{array}$ & $\begin{array}{c}\text { TM spectral range } \\
(\mu \mathrm{m})\end{array}$ & $\begin{array}{c}\text { ETM+ } \\
\text { spectral range } \\
(\mu \mathrm{m})\end{array}$ & $\begin{array}{c}\text { ALI } \\
\text { band number }\end{array}$ & $\begin{array}{c}\text { ALI } \\
\text { spectral range } \\
(\mu \mathrm{m})\end{array}$ & Description \\
\hline Pan & -- & $0.52-0.90$ & Pan & $0.480-0.690$ & panchromatic \\
\hline-- & -- & -- & $1\left(\mathrm{MS}-1^{\prime}\right)$ & $0.433-0.453$ & VNIR (blue) \\
\hline 1 & $0.450-0.520$ & $0.45-0.515$ & 2 (MS-1) & $0.450-0.515$ & VNIR (blue) \\
\hline 2 & $0.520-0.600$ & $0.525-0.605$ & 3 (MS-2) & $0.525-0.605$ & VNIR (green) \\
\hline 3 & $0.630-0.690$ & $0.63-0.690$ & 4 (MS-3) & $0.630-0.690$ & VNIR (red) \\
\hline 4 & $0.760-0.900$ & $0.75-0.90$ & 5 (MS-4) & $0.775-0.805$ & VNIR \\
\hline-- & -- & -- & $6\left(\mathrm{MS}-4^{\prime}\right)$ & $0.845-0.890$ & VNIR \\
\hline-- & -- & -- & $7\left(\mathrm{MS}-5^{\prime}\right)$ & $1.200-1.300$ & SWIR \\
\hline 5 & $1.550-1.750$ & $1.55-1.750$ & 8 (MS-5) & $1.550-1.750$ & SWIR \\
\hline 6 & $1.40-12.50$ & $1.40-12.50$ & -- & -- & TIR \\
\hline 7 & $2.080-2.350$ & $2.09-2.35$ & 9 (MS-7) & $2.080-2.350$ & SWIR \\
\hline
\end{tabular}

\section{Methods}

\section{Study Sites and Dataset}

To best investigate the appropriation of using a Landsat TC matrix for ALI, the study sites were chosen to represent different geographic areas, and a range of moisture (precipitation) and vegetation regimes in the contiguous United States. The five study sites are located in California, Colorado, Georgia, Missouri, and an area bordering West Virginia, Pennsylvania, Virginia, and Maryland (fig. 1). The ecoregions represented are California Coastal Sage, Chaparral, and Oak Woodlands ecoregion of the Mediterranean California region (California); High Plains ecoregion of the Great Plains region (Colorado); Southeastern Plains ecoregion of the Eastern Temperate Forests region (Georgia); Ozark Highlands, ecoregion of the Eastern Temperate Forests region (Missouri); and Central Appalachians/Ridge and Valley ecoregion of the Eastern Temperate Forests region (West Virginia) (Environmental Protection Agency, 2006) (ecoregions not shown in figure 1). Site differences illustrate the utility of our approach for different climate areas for the possibility of expansion into larger areas (table 2). Although nonvegetated areas with high reflectance would have been ideal to best compare radiometric details of ALI images with TM images, the goal was to test suitability for a variety of real-world scenarios.

A total of 20 orthorectified images were used (table 3). The Landsat TM images had Level 1T (L1T) processing applied and the ALI images were Level 1Gst (L1Gst), resulting in radiometrically and geometrically corrected images. Four images were used per site, with two corresponding
Landsat TM and ALI images chosen for two different dates between 2001 and 2008. Two dates per site were used to capture the variance of moisture (precipitation) and vegetation conditions with time. Selected images were cloud-free in the areas of overlap and had a difference of less than 10 days between the dates of acquisition.

Landsat TM images were used to eliminate the inclusion of Landsat ETM+ images with the Scan Line Corrector (SLC) off. In addition, a high correlation between Landsat TM and ALI images using similar methods was reported in an abstract by Finn and others (2006). However, as the EO-1 satellite was designed to fly in formation with Landsat 7, the inclusion of one Landsat ETM+ image from 21 March 2003, row 43, path 34 also was used for comparison.

\section{Description of Methods}

All images used in the study were converted to radiance, top of atmosphere (TOA) reflectance, and TC images (fig. 2). The conversions to radiance and reflectance were completed using methods outlined in Chander and others (2009). The coefficients for specific Landsat image spectral bands corresponding to the ALI bands (table 1) were applied using the TC matrices for either TM or ETM+ (Crist 1985; Huang and others, 2002).

For each matched pair of images (similar dates and same row/path), 30 random points were extracted from the area of overlap (fig. 3). Spectral information for each point was then extracted from each pertinent reflectance, radiance, and TC band. Linear regression was used to test the relation between the Landsat TM and the ALI images. 


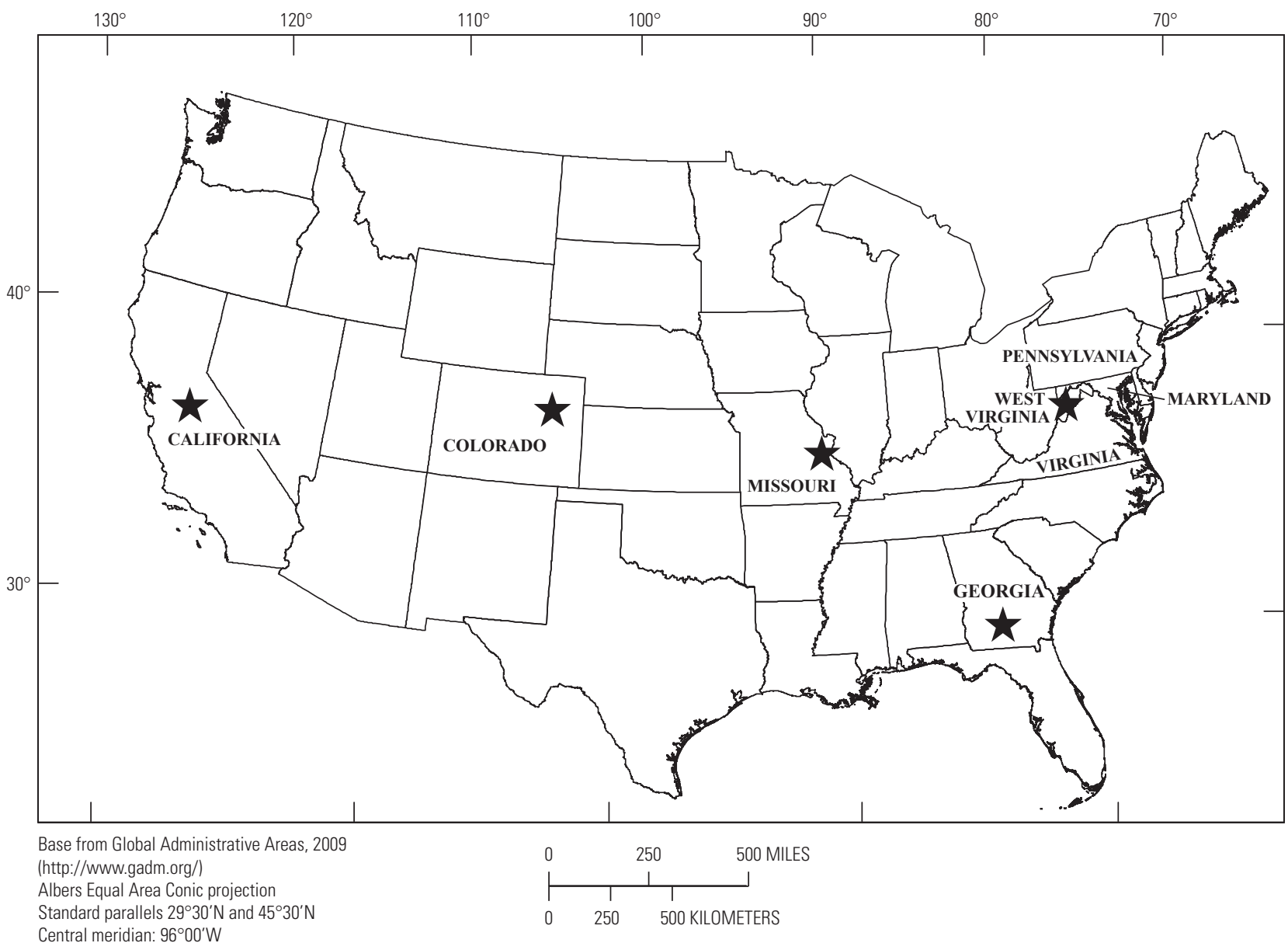

Figure 1. Location of study sites (table 2).

Table 2. Climate information for study sites.

[Data obtained for weather station nearest the center of each image pair (National Oceanic and Atmospheric Administration, 2011)]

\begin{tabular}{|c|c|c|c|c|c|}
\hline & California & Colorado & Georgia & Missouri & West Virginia $^{1}$ \\
\hline \multicolumn{6}{|c|}{ Monthly mean temperature (degrees Fahrenheit) } \\
\hline January & 47.0 & 28.0 & 48.9 & 28.6 & 31.4 \\
\hline February & 51.4 & 29.3 & 50.4 & 34.5 & 31.7 \\
\hline March & 56.9 & 38.9 & 65.5 & 45.1 & 41.5 \\
\hline April & 60.5 & 47.3 & 73.7 & 56.1 & 52.9 \\
\hline May & 69.4 & 57.0 & 79.5 & 62.7 & 60.6 \\
\hline June & 75.6 & 67.3 & 81.7 & 71.6 & 69.9 \\
\hline July & 79.9 & 74.9 & 81.7 & 77.6 & 72.6 \\
\hline August & 78.0 & 72.2 & 81.5 & 75.0 & 73.1 \\
\hline September & 73.4 & 62.4 & 77.1 & 65.9 & 65.4 \\
\hline October & 64.4 & 49.0 & 68.1 & 54.9 & 53.5 \\
\hline November & 54.1 & 38.5 & 58.3 & 43.0 & 44.3 \\
\hline December & 47.7 & 26.8 & 50.8 & 33.2 & 34.2 \\
\hline \multicolumn{6}{|c|}{ Average annual precipitation (inches) } \\
\hline & 11.6 & 15.1 & 46.3 & 38.6 & 34.6 \\
\hline
\end{tabular}

${ }^{1}$ Area bordering West Virginia, Pennsylvania, Virginia, and Maryland. 
Table 3. List of Landsat TM and ALI images used in the study.

[TM, Thematic Mapper; ALI, Advanced Land Imager; --, no data]

\begin{tabular}{|c|c|c|c|c|}
\hline $\begin{array}{c}\text { Study site } \\
\text { (fig. 1) }\end{array}$ & Sensor & Date & $\begin{array}{l}\text { Row/ } \\
\text { path }\end{array}$ & $\begin{array}{l}\text { Look } \\
\text { angle }\end{array}$ \\
\hline California & ALI & Sept. 19, 2008 & $42 \_34$ & -16.407 \\
\hline California & Landsat & Sept. 11, 2008 & $42 \_34$ & -- \\
\hline California & ALI & Mar. 21, 2003 & $43 \_34$ & -1.794 \\
\hline California & Landsat & Mar. 29, 2003 & $43 \_34$ & -- \\
\hline Colorado & ALI & Oct. 20, 2004 & $32 \_33$ & 2.928 \\
\hline Colorado & Landsat & Oct. 28, 2004 & $32 \_33$ & -- \\
\hline Colorado & ALI & May 12, 2001 & $33 \_32$ & 6.519 \\
\hline Colorado & Landsat & May 20, 2001 & $33 \_32$ & -- \\
\hline Georgia & ALI & Dec. 21, 2004 & $18 \_37$ & 1.151 \\
\hline Georgia & Landsat & Dec. 13,2004 & $18 \_38$ & -- \\
\hline Georgia & ALI & June 15,2006 & $18 \_38$ & -5.534 \\
\hline Georgia & Landsat & June 10, 2006 & $18 \_38$ & -- \\
\hline Missouri & ALI & Sept. 26, 2004 & $24 \_33$ & 1.449 \\
\hline Missouri & Landsat & Oct. 4, 2004 & $24 \_33$ & -- \\
\hline Missouri & ALI & Sept. 25, 2001 & $24 \_34$ & 12.690 \\
\hline Missouri & Landsat & Sept. 26, 2001 & $24 \_34$ & -- \\
\hline West Virginia & ALI & July 9, 2007 & $17 \_32$ & 5.359 \\
\hline West Virginia & Landsat & July 8, 2007 & $17 \_32$ & -- \\
\hline West Virginia & ALI & Nov. 4, 2001 & $17 \_33$ & 5.642 \\
\hline West Virginia & Landsat & Nov. 12, 2001 & $17 \_33$ & -- \\
\hline
\end{tabular}

\section{Results}

The initial results did not show a strong relation between Landsat TM and ALI images for all scenes used. The coefficient of determination, $\mathrm{R}^{2}$, varied between 0.814 and 0.001 . There were no clear patterns for determining higher $\mathrm{R}^{2}$ values, as $\mathrm{R}^{2}$ values differed between bands and between images (table 4). Within an image pair, the values from a random point for one band combination did not dictate similar trends for the

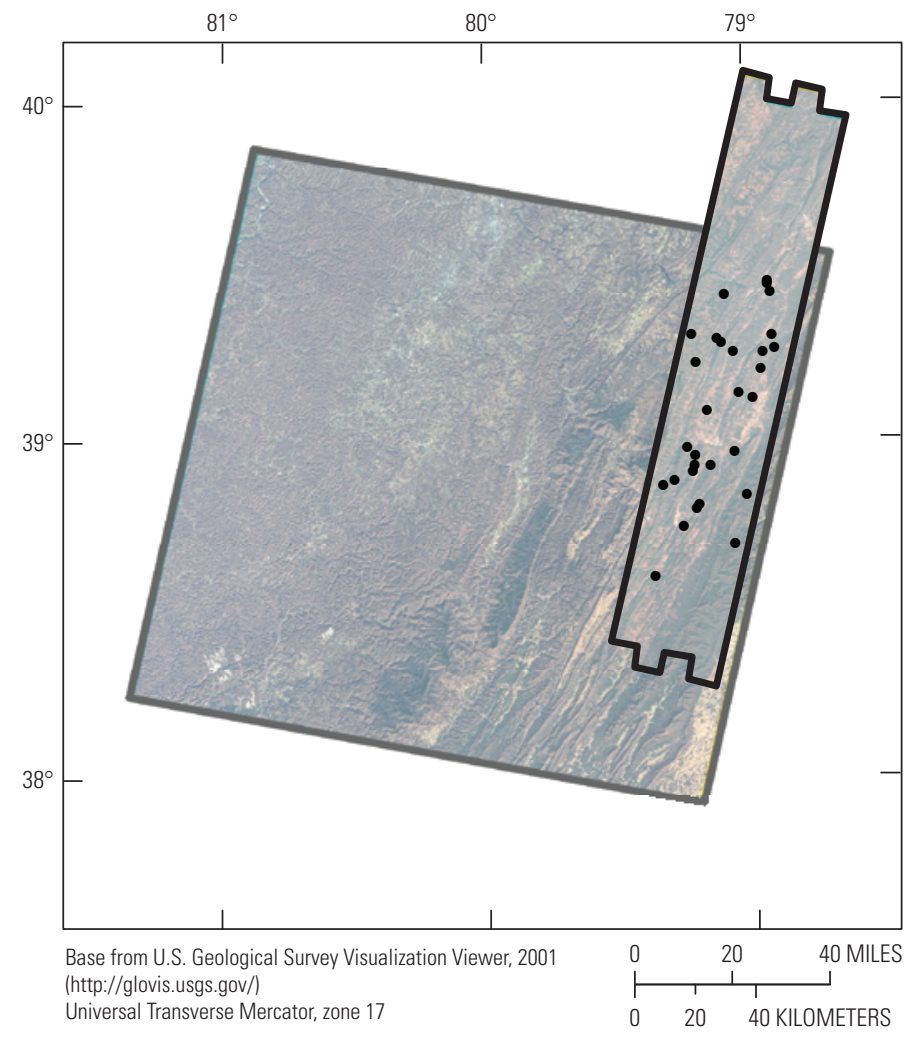

EXPLANATION

[ALI, Advanced Land Imager; TM, Thematic Mapper; TC, Tassled Cap]

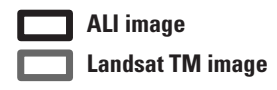

- Random point-represents 30 randomly chosen points from which spectral information was extracted for the radiance, reflectance, and TC images

Figure 3. ALI image superimposed over Landsat 5 image (row 17 path 33) from November 2001.

other band combinations (fig. 4). Band combinations with high $\mathrm{R}^{2}$ values for reflectance did not necessarily have high $\mathrm{R}^{2}$ values for TC comparisons, nor was the inverse true (figs. 5 and 6). Results were similar for the Landsat ETM+ and ALI image comparison (table 5). When comparing radiance and reflectance values for the same pixel in the two images, relations are preserved and therefore generate equal $\mathrm{R}^{2}$ values.

To account for possible geolocation errors, a sampling algorithm of the nearest eight neighbors of each random

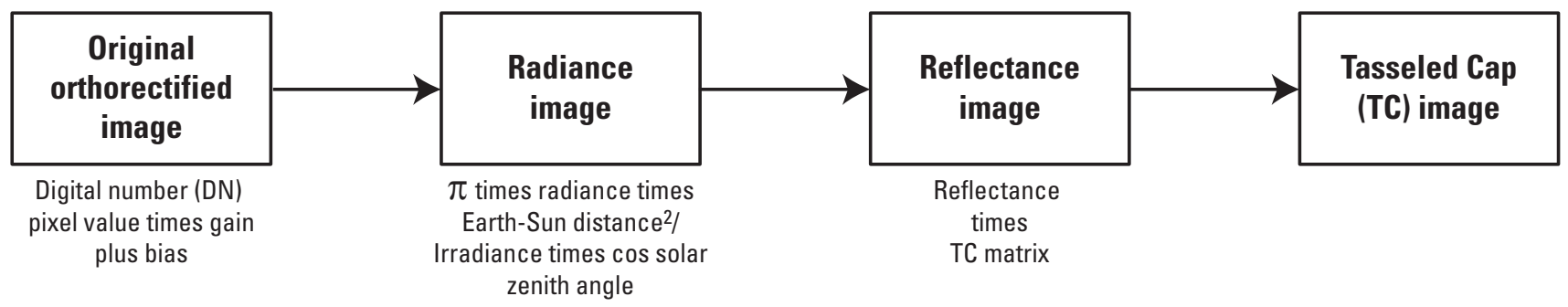

Figure 2. Steps to convert the original imagery to radiance, reflectance, and TC images. 
Table 4. $R^{2}$ values for radiance, reflectance, and TC for each pair of images.

[TC, Tasseled Cap; each image is represented by its location, row and path, and image date, as designated in the columns immediately left of the band pairs; TM, Thematic Mapper; ALI, Advanced Land Imager]

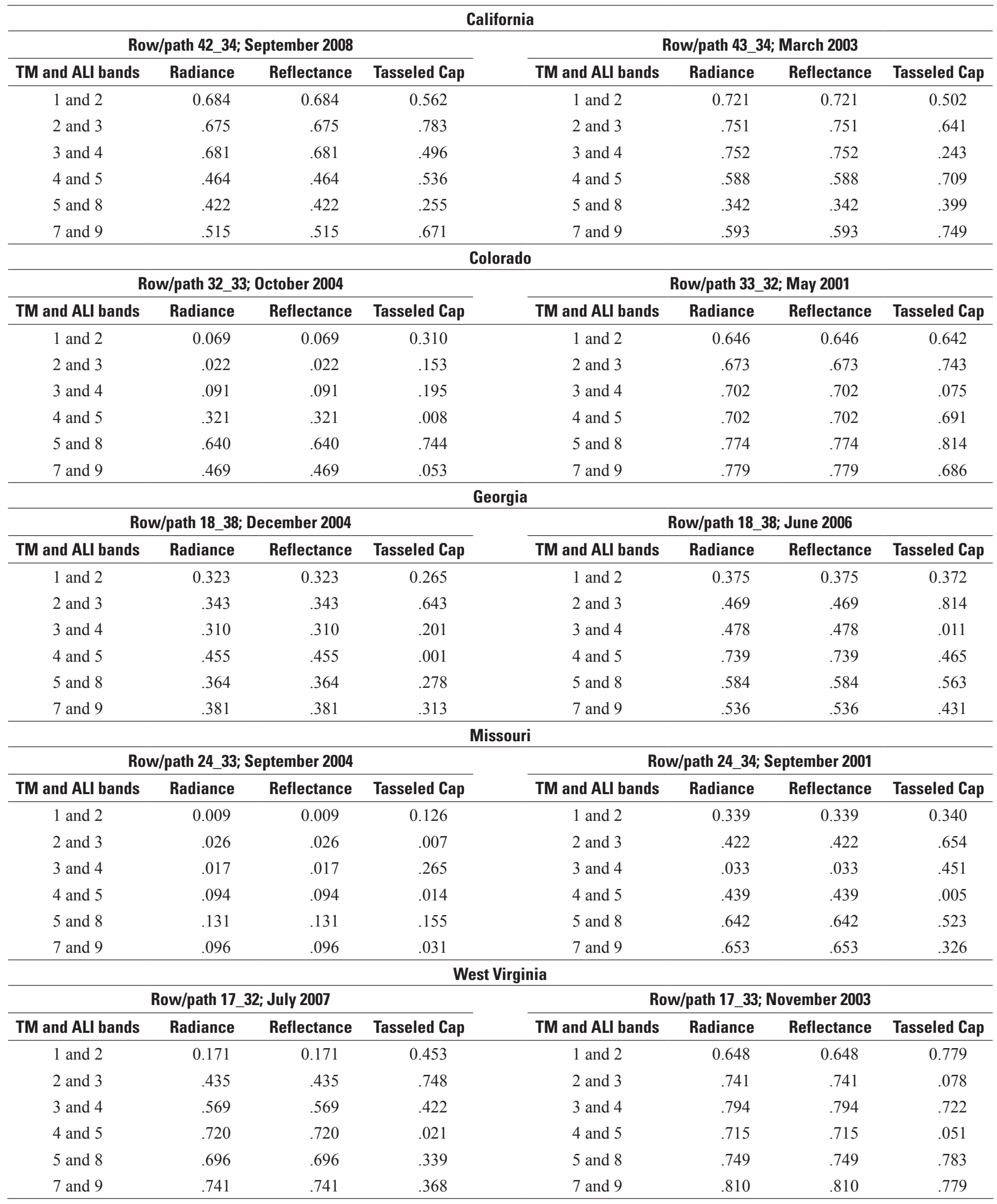




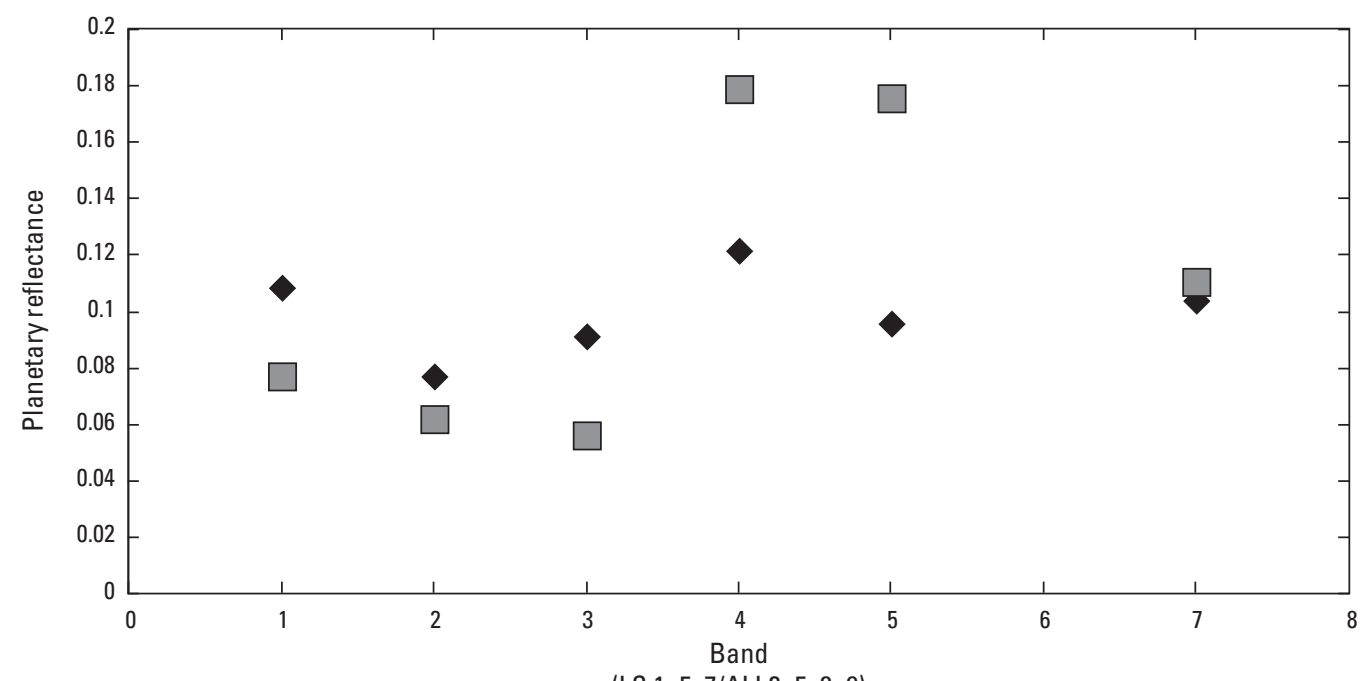

EXPLANATION

[ALI, Advanced Land Imager; LS, Landsat; TM, Thematic Mapper; TOA, top of atmosphere]

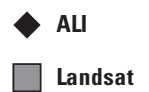

Note: There is a closer correspondence for some points (for example, Landsat TM band $7 / A L I$ band 9 ) than others (for example, Landsat TM band $5 / \mathrm{ALI}$ band 8 ).

(LS 1-5, 7/ALI 2-5, 8-9)

Figure 4. ALI and Landsat TM TOA reflectance values for a sample point in the West Virginia, row 17 path 33, November 2001, image pair.
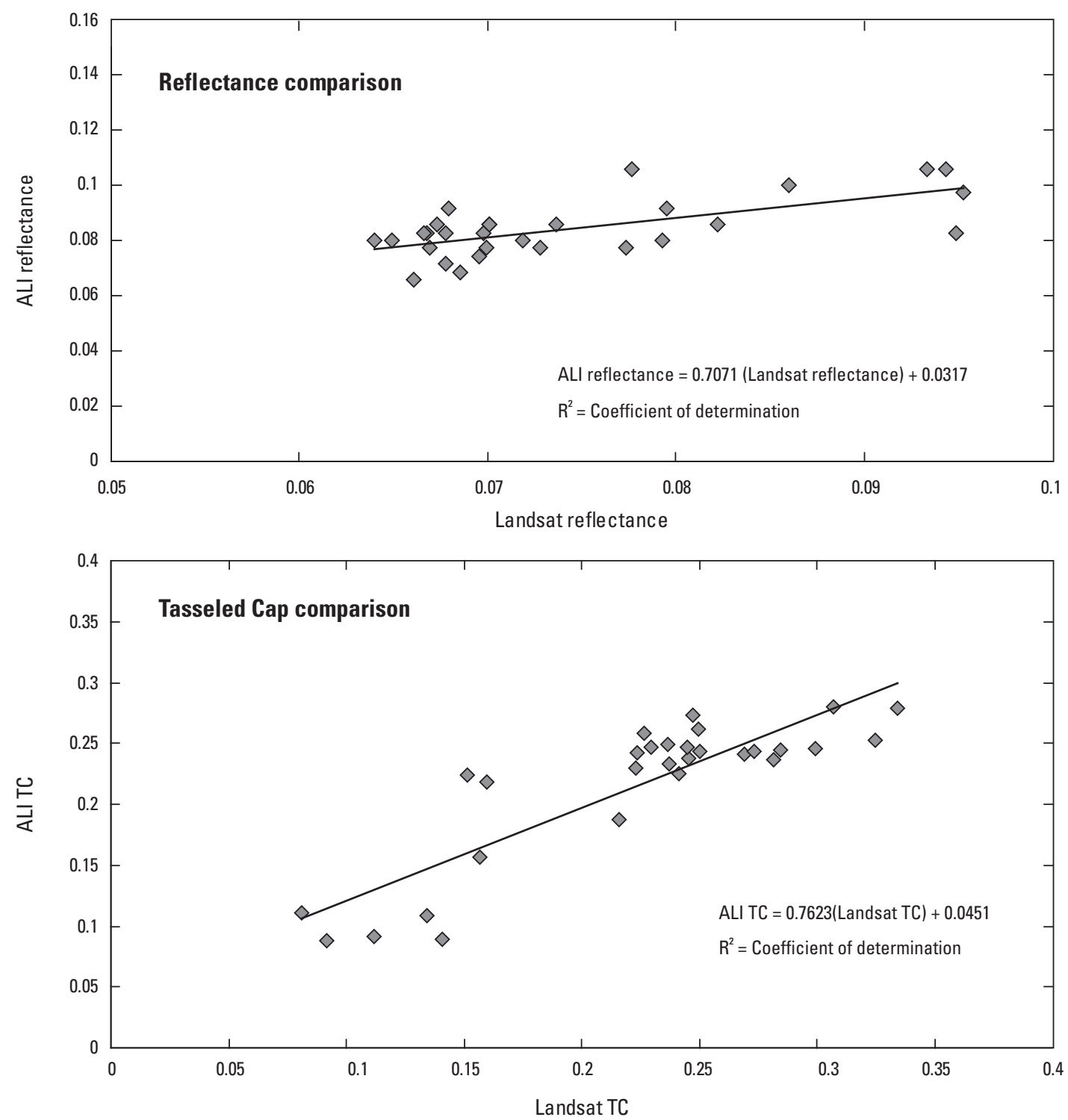

Figure 5. $\mathrm{ALI}$ and Landsat TM TOA reflectance and TC values for Landsat band 2/ALI band 3 for the West Virginia, row 17 path 32, July 2007 image pair. 


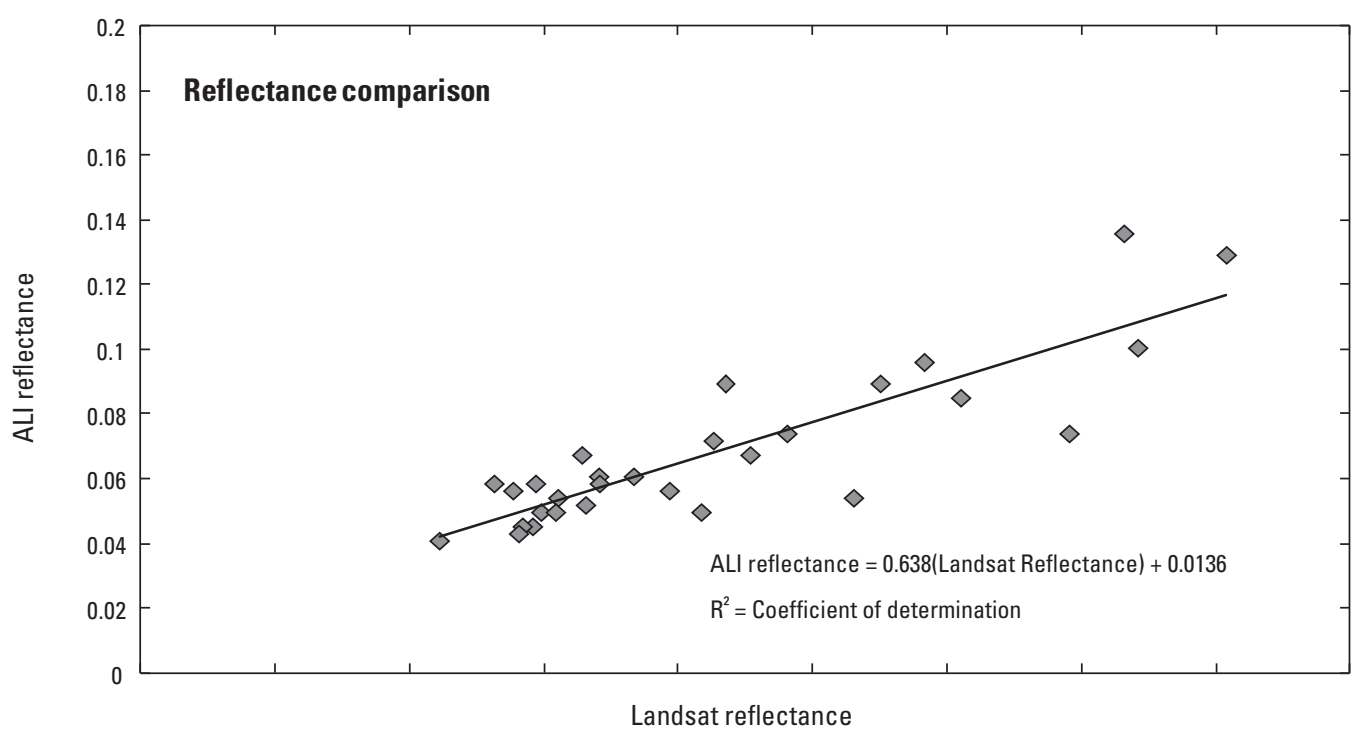

EXPLANATION

ALI Advanced Land Imager

LS Landsat

TM Thematic Mapper

TOA Top of atmosphere

TC Tasseled Cap

Note: The $R^{2}$ value for reflectance is high but the $R^{2}$ value for $T C$ is low.

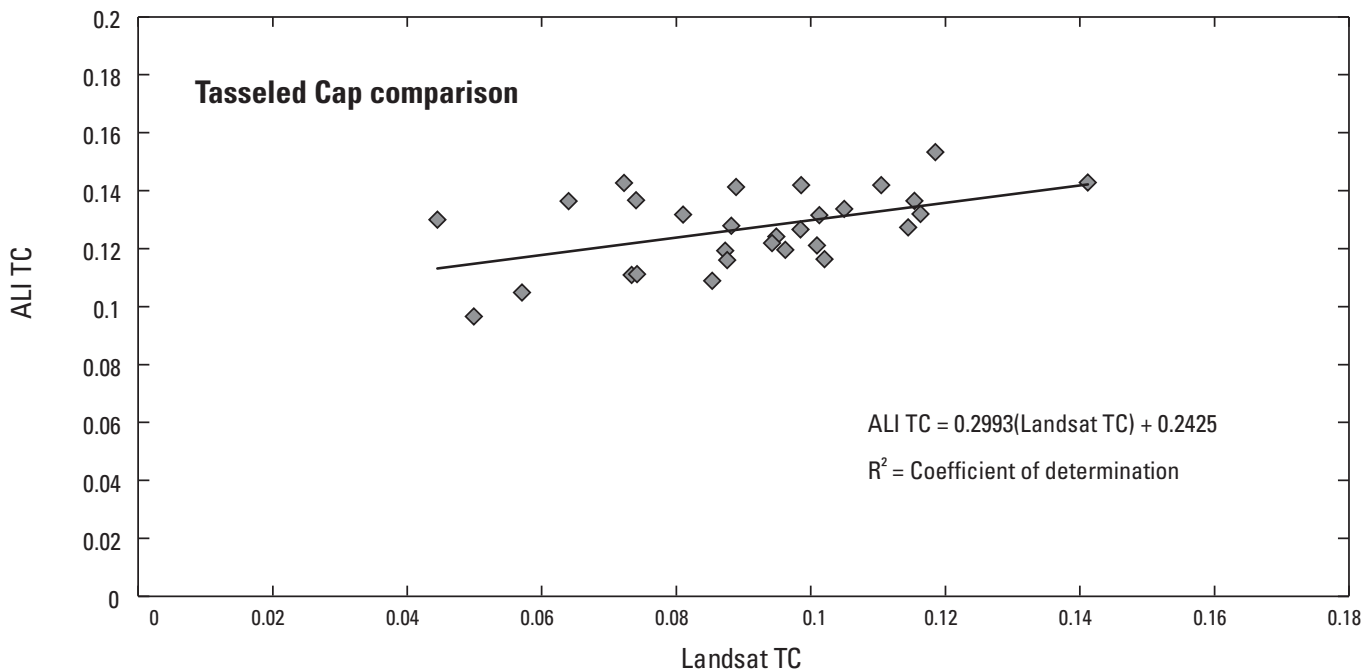

Figure 6. ALI and Landsat TM TOA reflectance and TC values for Landsat band 3/ALI band 4 for the California, row 43 path 34 , March 2003 image pair.

Table 5. $\quad R^{2}$ values for radiance, TOA reflectance, and TC for Landsat ETM+ and ALI image pair

[TOA, top of atmosphere; TC, Tasseled Cap; ETM+, Enhanced Thematic Mapper Plus; ALI, Advanced Land Imager; ETM, Enhanced Thematic Mapper]

\begin{tabular}{ccc}
\hline \multicolumn{3}{c}{ California } \\
\hline ETM and ALI bands & Radiance/reflectance & Tasseled Cap \\
\hline 1 and 2 & 0.671 & 0.330 \\
2 and 3 & .576 & .628 \\
3 and 4 & .673 & .077 \\
4 and 5 & .561 & .373 \\
5 and 8 & .327 & .352 \\
7 and 9 & .546 & .608 \\
\hline
\end{tabular}


point's pixel instead of the single pixel was run for two pairs of images. Although this method increased the relation between the ALI and Landsat images from the single pixel, again, relations were not universally high (table 6).

\section{Discussion}

The TC transformations on Landsat MSS, TM, and ETM+ are used regularly to find measures of brightness, greenness, wetness, and other characteristics from a remotely sensed image. Despite the spectral, temporal, and spatial similarities, Landsat TM and ALI images do not universally correlate well in regards to reflectance and radiance values. Thus, the TM TC coefficient matrix cannot be used with the ALI images.

Generally the ALI sensor was designed to mimic the ETM + sensor, which was, in turn, designed to complement previous Landsat sensors, spectral and spatial similarities between ALI and Landsat exist. The two sensors do not, however, correlate well for the scenes used in this study and it is apparent that such similarities do not warrant equal values for all scenes and areas covered by the satellites. There are several possible explanations for such differences.

Although the best choices of cloud-free image pairs relatively near an acquisition date were used for each study area, a gap of several days between the TM and ALI images was unavoidable. It is possible that this span of time could result in differences in vegetation and atmospheric conditions, especially as images were not chosen to fall in vegetation-free areas.

Although one of its inherent strengths, the ability of the EO-1 satellite to perform cross-track pointing also may contribute to the weaknesses in correlation, because the look angles of Landsat 5 and 7 remain constant at near-nadir. Another possible explanation is the difference in radiometric resolution of the data sources. Landsat TM and ETM+ are scaled to 8-bit, whereas ALI is scaled to 16-bit, as a result of radiometric calibration. In addition, because the relative spectral response functions differ between the sensors, their interchangeability in the use of a TC matrix may suffer.

Based on these results, a TC matrix specific to ALI imagery needs to be developed. The striping effects of SLC-Off for Landsat 7 can be hidden by resampling methods, and for those studies that will not be affected detrimentally by these efforts, Landsat 7 can continue to be a valid option. Studies that require an image without such resampling and for an image acquisition date that ALI can provide then ALI imagery reamains a viable alternative. ALI data also are preferred when a look angle other than near-nadir is needed, or if the footprint of the ALI image covers the study area, which eliminates the need for image mosaicing and issues with differing acquisition dates. The ability to extract brightness, greenness, and wetness information from ALI imagery remains out of reach without a TC matrix.

Table 6. $R^{2}$ values for radiance, TOA reflectance, and TC for Landsat ETM+ and ALI image after sampling algorithm run.

[TOA, top of atmosphere; TC, Tasseled Cap; ETM+; Enhanced Thematic Mapper Plus; ALI, Advanced Land Imager; TM, Thematic Mapper]

\begin{tabular}{ccc}
\hline \multicolumn{3}{c}{ California } \\
\hline \multicolumn{3}{c}{ Row/path 43_34; March 2003 } \\
\hline TM and ALI bands & Radiance/reflectance & Tasseled Cap \\
\hline 1 and 2 & 0.859 & 0.791 \\
2 and 3 & .865 & .835 \\
3 and 4 & .872 & .615 \\
4 and 5 & .821 & .599 \\
5 and 8 & .649 & .697 \\
7 and 9 & .819 & .873 \\
\hline
\end{tabular}

\begin{tabular}{ccc}
\hline \multicolumn{3}{c}{ Colorado } \\
\hline \multicolumn{3}{c}{ Row/path 32_33; October 2004 } \\
\hline TM and ALI bands & Radiance/reflectance & Tasseled Cap \\
\hline 1 and 2 & 0.142 & 0.485 \\
2 and 3 & .104 & .241 \\
3 and 4 & .167 & .635 \\
4 and 5 & .447 & .002 \\
5 and 8 & .731 & .756 \\
7 and 9 & .595 & .146 \\
\hline
\end{tabular}




\section{References Cited}

Bannari, A., Guedon, A.M., El-Harti, A., Cherkaoui, F.Z., and El-Ghmari, A., 2008, Characterization of slightly and moderately saline and sodic soils in irrigated agricultural land using simulated data of advanced land imaging (EO-1) sensor: Communications in Soil Science and Plant Analysis, v. 39, p. 2,795-2,811, doi: 10.1080/00103620802432717.

Bindschadler, R.A., Scambos, T.A., Choi, H.,and Haran, T.M., 2010, Ice sheet change detection by satellite image differencing: Remote Sensing of Environment, v. 114, p. 1,353-1,362. doi: 10.1016/j.rse.2010.01.014.

Chander, G., Meyer, D.J., and Helder, D.L., 2004, Cross calibration of the Landsat-7 ETM+ and EO-1 ALI sensor: IEEE Transactions on Geoscience and Remote Sensing. v. 42, p. 2,821-2,831. doi: 10.1109/tgrs.2004.836387.

Chander, G., Markham, B.L,.and Helder, D.L., 2009, Summary of current radiometric calibration coefficients for Landsat MSS, TM, ETM+, and EO-1 ALI sensors: Remote Sensing of Environment, v. 113, p. 893-903, doi: 10.1016/j. rse.2009.01.007.

Chen, S.S., Fang, L.G., Zhang, L.X., and Huang, W.R., 2009, Remote sensing of turbidity in seawater intrusion reaches of Pearl River Estuary-A case study in Modaomen water way, China: Estuarine Coastal and Shelf Science, v. 82, p. 119-127, doi: 10.1016/j.ecss.2009.01.003.

Crist, E.P., 1985, A TM Tasseled Cap equivalent transformation for reflectance factor data: Remote Sensing of Environment, v. 17, p. 301-306.

Crist, E.P., and Cicone, R.C., 1984, Comparisons of the dimensionality and features of simulated Landsat-4 MSS and TM data: Remote Sensing of Environment, v. 14, p. 235-246.

Crist, E.P., and Kauth, R.J., 1986, The tasseled cap de-mystified: Photogrammetric Engineering and Remote Sensing, v. 52, p. 81-86.

DeRose, R.J., Long, J.N., and Ramsey, R.D., 2011, Combining dendrochronological data and the disturbance index to assess Engelmann spruce mortality caused by a spruce beetle outbreak in southern Utah, USA: Remote Sensing of Environment, v. 115, p. 2,342-2,349, doi: 10.1016/j. rse.2011.04.034.

U.S. Environmental Protection Agency, 2006, U.S. Environmental Protection Agency: Ecological Regions of North America, U.S. Environmental Protection Agency.
Finn, M.P., Usery, E.L., and Reed, M., 2006, A first approximation of tasseled-cap values for the Advanced Land Imager: ISPRS Commission VIII Symposium on "Remote Sensing Applications for a Sustainable Future”, Haifa, Israel.

Gutierrez, M., and Johnson, E., 2010, Temporal variations of natural soil salinity in an arid environment using satellite images: Journal of South American Earth Sciences, v. 30, p. 46-57, doi: 10.1016/j.jsames.2010.07.005.

Helmer, E.H., Ruzycki, T.S., Wunderle, J.M., Vogesser, S., Ruefenacht, B., Kwit, C., Brandeis, T.J., and Ewert, D.N., 2010, Mapping tropical dry forest height, foliage height profiles and disturbance type and age with a time series of cloud-cleared Landsat and ALI image mosaics to characterize avian habitat: Remote Sensing of Environment, v. 114, p. 2,457-2,473, doi: 10.1016/j.rse.2010.05.021.

Horne, J.H., 2003, A Tasseled Cap transformation for Ikonos images: ASPRS 2003 Annual Conference Proceedings, Anchorage, Alaska.

Huang, C., Wylie, B., Yang, L., Homer, C., and Zylstra, G., 2002, Derivation of a tasseled cap transformation based on Landsat 7 at-satellite reflectance: International Journal of Remote Sensing, 23, 1741-1748. doi: 10.1080/01431160110106113.

Jensen, J.R., 2005, Introductory digital image processing: A remote sensing perspective, 3rd ed.: Upper Saddle River, N.J., Prentice-Hall.

Kauth, R.J., and Thomas, G.S., 1976, The tasselled cap-A graphic description of the spectral-temporal development of agricultural crops as seen by Landsat: Symposium Proceedings, Machine Processing of Remotely Sensed Data, Laboratory for Applications of Remote Sensing, West Lafayette, Indiana, Purdue University.

Lobser, S.E., and Cohen, W.B., 2007, MODIS tasselled capland cover characteristics expressed through transformed MODIS data: International Journal of Remote Sensing, v. 28, p. 5,079-5,101, doi: 10.1080/01431160701253303.

National Oceanic and Atmospheric Administration, 2011, National Climatic Data Center, Web Climate Services Version 2.1, National Oceanic and Atmospheric Administration.

Ouma, Y.O., and Tateishi, R., 2006, A water index for rapid mapping of shoreline changes of five East African Rift Valley lakes: an empirical analysis using Landsat TM and ETM+ data: International Journal of Remote Sensing, v. 27, p. 3,153-3,181, doi: 10.1080/01431160500309934. 
Running, S.W., Justice, C.O., Salomonson, V., Hall, D., Barker, J., Kaufmann, Y.J., Strahler, A.H., Huete, A.R., Muller, J.P., Vanderbilt, V., Wan, Z.M., Teillet, P., and

Carneggie, D., 1994, Terrestrial remote-sensing science and algorithms planned for EOS MODIS: International Journal of Remote Sensing, v. 15, p. 3,587-3,620.

Schroeder, T.A., Wulder, M.A., Healey, S.P., and Moisen, G.G., 2011, Mapping wildfire and clearcut harvest disturbances in boreal forests with Landsat time series data: Remote Sensing of Environment, v. 115, p. 1,421-1,433, doi: 10.1016/j.rse.2011.01.022.

Wang, Y., and Sun, D., 2005, The ASTER tasseled cap interactive transformation using Gramm-Schmidt method, in L. Zhang, and others, eds., Proceedings of the SPIE.

Zhang, X., Schaaf, C.B., Friedl, M.A., Strahler, A.H., Gao, F., and Hodges, J.C.F., 2002, MODIS tasseled cap transformation and its utility: Proceedings of the International Geoscience and Remote Sensing Symposium (IGARSS '02), p. $1,063-1,065$.

Publishing support provided by:

Rolla Publishing Service Center

For more information concerning this publication, contact:

Director, USGS National Geospatial Technical Operations Center

1400 Independence Road

Rolla, M0 65401

(573) 308-3500

Or visit the National Geospatial Technical Operations Center Web site at:

http://ngtoc.usgs.gov/ 

